\title{
Shipping operations support in the "High North": examining availability of icebreakers along the Northern Sea Route
}

\author{
Dimitrios Dalaklis $^{1}$ (D) Megan L. Drewniak ${ }^{1,2}$ • \\ Jens-Uwe Schröder-Hinrichs ${ }^{1}$
}

Received: 4 November 2017 / Accepted: 16 March 2018 /Published online: 17 April 2018

(C) World Maritime University 2018

\begin{abstract}
A rather significant number of business entities already operate within (or, have considered to exploit) the Arctic region, focusing upon previously untapped resources such as precious minerals and large quantities of oil and gas; touristic and fishing activities are clearly on the rise, with various endeavors of maritime transport also being put forward. Up until recently, harsh year-long environmental conditions have significantly hindered the necessary access and transport connections in the Arctic. Even in the case that weather conditions did permit vessels' passage, unreliable navigational aids and lack of infrastructure/support provided obstacles difficult to overcome. However, environmental data recorded during the last couple of decades clearly indicates that there is a continuous decline of ice coverage in the "High North." Given this steady decline, the Arctic has now been viewed as a promising field for economic activities and is considered as a potential connecting corridor between Asia and Europe/America (and vice-versa). As human presence and operations are expected to intensify there, it is of utmost importance to evaluate the current level of support towards ships that will be crossing the region; capabilities in relation to search and rescue (SAR) operations and oil spill response are also important. The analysis in hand will first deliver a discussion of the so-called Arctic Passages. While various different maritime routes have been proposed in relation to the Arctic, the most promising one, the Northern Sea Route (NSR), will provide the epicenter of discussion. Through an extensive literature review that includes numerous internet resources, the current
\end{abstract}

The views herein are solely of the authors and do not represent the views of the United Nations/World Maritime University, or the Department of Homeland Security/US Coast Guard, or any other organization with a similar scope.

Dimitrios Dalaklis

dd@wmu.se

1 World Maritime University (WMU), Malmö, Sweden

2 United States Coast Guard on Secondment, Martin Luther King Jr Ave SE, Washington, DC, USA 
analysis will identify the numbers of icebreakers already operating in the NSR, as well as those that will be commissioned into service in the near future. The choice to research the specific type of vessels is supported by a simple argument: icebreakers currently are and will continue to be in the foreseeable future the main "tool" to support shipping activities in the Arctic. Furthermore, emergency management capabilities in the Russian Arctic will be examined to include the current state of rescue coordination centres along with the availability of SAR assets. Additionally, the efforts thus far by the Arctic Council to increase coordination and interaction among the States involved in Arctic affairs will be summarized; the latter will be achieved via a brief review of a very important legally binding agreement: the "search and rescue" instrument. In conclusion, the Russian State has already heavily invested in icebreakers' building and their current number is fully capable to handle the present level of limited traffic. On the other hand, ships are currently faced with long distances to cross (often without adequate support) adverse environmental conditions, unpredictable hurdles, and slow response times in case of an emergency. Therefore, in case ships operating in the region are increased, it will be difficult to deal with all the additional demands for support. Of particular interest is the fact that considering the vast area of the NSR, the overall available response capabilities in the region under discussion are rather thin; any further increase of maritime traffic in the "High North" must be balanced with additional strengthening of emergency management capabilities. In any case, should the NSR become fully integrated in the global maritime transport system, Russia's geopolitical status will be clearly improved and further research is needed to discuss the implications both at the regional and global levels.

Keywords Arctic · High North · Northern Sea Route (NSR) - Shipping operations · Icebreakers' services $\cdot$ Search and rescue (SAR)

\section{Introduction}

Until recently, the Arctic region was widely considered a harsh/unapproachable environment rather unsuitable for economic activities, mainly for a self-explanatory reason: dire year-long environmental conditions which, at the minimum, severely hindered or even completely blocked the necessary access and transport connections (Dalaklis and Baxevani 2017). For the last couple of decades, when referring to the worldwide volume of maritime traffic, the total contribution of the Arctic region was (and remains) rather small (UNCTAD 2016). However, unprecedented climate change (including a significant decline of the associated ice coverage, as well as rising air and sea temperatures) combined with various technological advances that are now available to mitigate the still adverse environmental conditions provides an extraordinary opportunity to capitalize on a plethora of Arctic business opportunities. An Arctic with a "lesser ice" status is considered a very promising field for various economic activities, such as offshore energy and exploration, mining of minerals, fishing, tourism, and, last but not least, maritime transport endeavors (Drewniak et al. 2017). The prospect of shorter voyages from Asia towards Europe and/or the Americas (and vice-versa) is very enticing for numerous shipping companies as well as various other actors within the extended maritime transport industry; their future plans are strongly influenced by the 
fact that navigation along the main "Arctic Passages," namely the Northern Sea Route (NSR) and the Northwest Passage (NWP), is becoming more and more feasible (Dalaklis et al. 2016).

Before proceeding any further, it is necessary to note that for the purposes of the analysis in hand, the "Arctic" is defined as the area containing the Arctic Ocean as well as the respective territories of the states with a latitude higher than the Arctic Circle $\left(66^{\circ} 33^{\prime} 46.7^{\prime \prime} \mathrm{N}\right) .^{1}$ To provide a better idea of the statistics involved, the area north of the Arctic Circle is about 20 million square kilometers ( 7.7 million square miles) and covers roughly $4 \%$ of Earth's surface (Marsh and Kaufman 2012). This artificial line of division is passing through the Arctic Ocean, the Scandinavian Peninsula, North Asia, North America, and Greenland. As a result, the land within the Arctic Circle is divided among eight countries: Norway, Sweden, Finland, Russia, the United States of America-USA (Alaska), Canada, Denmark (Greenland), and Iceland (where it passes through the small offshore island of Grímsey). It is furthermore necessary to provide a special reference to those countries which have a (Arctic) coastline and can, therefore, raise claims regarding the continental shelf of the Arctic Ocean, namely Canada, the USA, Denmark, Norway, and Russia - the so-called Arctic 5. There is a simple explanation why all these countries have the right to project their sovereignty seawards according to the main legal instrument of oceans' governance: the 1982 United Nations' Convention on the Law of the Sea (UNCLOS). In fact, Denmark, Canada, Norway, and Russia have already made "formal" submissions concerning the Arctic seabed to the United Nations Commission on the Limits of the Continental Shelf (CLCS), which was established by UNCLOS. ${ }^{2}$

Examining at a very fine level of detail the latest environmental developments in the Arctic is not within the scope of the current analysis. However, it is useful to point out here that the previous years were nothing short of remarkable, as they highlighted environmental changes that continue to occur throughout the Arctic landscape. Arctic air temperatures have continued to rise, and the average annual surface air temperature anomaly $\left(+2.0^{\circ} \mathrm{C}\right.$ relative to the $1981-2010$ baselines) over land north of $60^{\circ} \mathrm{N}$ between October 2015 and September 2016 was by far the highest in the observational record beginning in 1900 (Richter-Menge et al. 2016). Furthermore, five of the first six months of 2016 set records for the smallest respective monthly sea ice extent since consistent satellite records began in 1979. More specifically, the pace of the Arctic sea ice retreat is increasing, currently at $13.3 \%$ per decade compared to the averages of 1981-2010 (Climate NASA 2016). The data about sea ice retreat in 2017 is not looking more favorable: Arctic's sea ice extent for January 2017 averaged 13.38 million square kilometers (5.17 million square miles), the lowest January extent in the 38-year satellite record (NSIDC 2017). The above mentioned scientifically recorded retreat of ice has

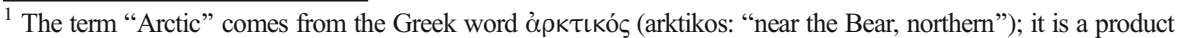

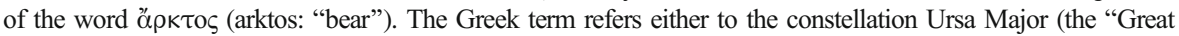
Bear"), which is prominent in the northern portion of the celestial sphere or to the constellation Ursa Minor (the "Little Bear"), which contains Polaris, the Pole star, also known as the North Star. Additionally, it is important to note that the position of the Arctic Circle is not fixed; as of 16 January 2018, it runs 66 $63^{\prime} 47.0^{\prime \prime}$ north of the equator. Additionally, considering that all areas that comprise the Arctic region are located in very high northern latitudes, the terms "Arctic" and "High North" are used interchangeably in the current analysis.

${ }^{2}$ Considering that the USA is not a signatory to UNCLOS, no submission concerning Arctic seabed has been made by them.
} 
made the High North more accessible; this fact also paved the way towards the extraction of energy resources available in the wider region, navigate faster shipping routes and engage in mining, fishing, and eco-tourism opportunities.

For the time being, the fastest available routes between North Atlantic and Asian Pacific ports for non-specialized vessels are along the so-called Northern Sea Route (NSR) and Northwest Passage (NWP). Voyage statistics for the NSR and NWP indicate increasing traffic (Eguíluz et al. 2016), although trans-Arctic voyage numbers are rather modest (Moe 2014). Additionally, there are various other contributors in vessels' traffic in the Arctic: various States in the region heavily rely on fishing activities as a tool to support their economy. There are approximately 214 fishing vessels registered in Northwest Russia and 3500 registered in the Northern Norway region (with 150 of them being large trawlers and pelagic fishing vessels). Furthermore, the Icelandic fishing fleet has remained fairly constant over the last decade and consist of approximately 1700 vessels (50 large vessels); fishing in Greenlandic waters is conducted by a limited number of shrimp trawlers and numerous small size boats (ranging between 1500 and 2000) (Borsch et al. 2016). With ice retreating, it is plausible that commercial fishing activities will increase in specific regions of the Arctic. At the same time, while so much focus is on Arctic shipping lanes as international transport corridors, little attention has been devoted to the upwards trend of the Arctic cruise industry (Hansen et al. 2016). In fact, over the last few decades, a significant increase in the number of passengers aboard Arctic cruise ships has been recorded.

This was especially evident between 2003 and 2007, where the annual number of passengers traveling to the Arctic with cruise ships more than doubled, although the number of passengers has stabilized in recent years. In the past, Arctic cruise ships that navigated the region were small in size and carried fewer passengers, but this trend has changed lately. For example, in August of 2016, the NWP became a mass tourism destination after the Crystal Serenity, a luxury cruise liner, successfully sailed through the NWP from Seward, Alaska, to New York City, with a crew of over 650 and a guest capacity of 1070 passengers. This journey would not have been possible without the diminishing sea ice conditions; it set a new record of the largest commercial cruise ship, weighing nearly 69,000 tons, to transit the NWP. Of significant concern is that while there is an increase in the number and size of cruise ships, the vast majority of them are not specifically designed to operate in Arctic waters. In addition to the potential major environmental disaster a ship of this magnitude presents in the case of an accident, the Arctic region is not appropriately equipped to handle the mass rescue operation should a disaster occur, requiring the evacuation of more than a thousand people.

The region under discussion is undergoing vast changes and at an unprecedented speed; it is indicative that there are predictions that put forward the notion that by the end of this century, the majority of the Arctic Ocean will be open water for more than half of the year (Barnhart et al. 2015). These radical changes could dramatically affect both the fragile ecosystem and the people that live/operate in the Arctic landscape; it is imperative to prepare for the future. The analysis in hand provides a very brief overview of all the passages that are associated with the Arctic (Arctic Passages); a detailed discussion of the NSR is following swiftly, considering that it is the most promising one (and associated with a higher level of traffic compared to NWP). It is crystal clear that for the time being, traffic varies from year-to-year and hindrances persist; the availability of icebreakers to keep the passages open and escort vessels 
crossing stands out as a primary concern. Therefore, an examination of icebreaker capabilities in relation to the NSR, along with the current state of rescue coordination centres and search and rescue assets, as well as spill response equipment and associated infrastructure, is conducted. An important issue already standing out is that there is a lot of room for improvement. Given the anticipated transition to an increasingly ice-free Arctic, an integral part of the current analysis is to highlight resource gaps concerning emergency management coordination and response in the Arctic region that may be used to assess the need to regulate or intervene to assure safety and sustainability in the High North.

\section{Arctic Passages}

During the late 1990s, navigation throughout the Arctic region was restricted solely to the summer months, given its icy and harsh environment; vessels were traditionally engaged to local destinations (small-sized ports) to meet the needs for basic goods. However, various areas that were previously covered by ice packs are now becoming increasingly available for shipping and remain ice-free for an extended period. Specifically, the days when navigation is possible are expected to follow an increasing trend: from around 70 days (currently) up to 125 in the year 2050 and as many as 160 in 2100 (Cariou and Faury 2015). The Northeast Passage (NEP) connects the Atlantic and Pacific Oceans through the eastern part of the Arctic Ocean; its boundaries are extending from Novaya Zemlya (west) to the Bering Strait (east). Its significance lies in its potential as an alternative to the Suez Canal Route, making the distance traveled between Asia and Europe around $40 \%$ shorter compared to crossing the Indian Ocean. The following section will concentrate on the portion of NEP along the northern Russian coastline, called the NSR, which has so far attracted the greatest majority of the Arctic maritime traffic. The NSR is defined as a separate part of the NEP, although it corresponds to $90 \%$ of its total extent, and is a legal entity under Russian jurisdiction (Council of People's Commissars of the U.S.S.R., 1932).

On the western edge of the Arctic Ocean, the NWP links the Atlantic and Pacific Oceans through the Canadian Arctic Archipelago. The number of vessels navigating these waters is significantly lower compared to the NSR. This is due to various reasons, including complex geography (there are many narrow and shallow corridors), as well as ocean currents, along with drifting ice packs that block many of the entrance and exit sites. Hinterland connection is another setback; venturing transport through the northern territories of Canada and Alaska has been characterized as the logistical equivalent of a lunar landing (Funkdec 2014). The NWP is mainly regarded as an alternative to the Panama Canal, though the investments on the latter to increase its size and crossing speed will help maintain its competitiveness in the near future. It is also necessary to note that despite the single term used, there are several potential routes a vessel can follow as much within the NWP as in the NSR (see Fig. 1). Vessels have to steer around numerous natural configurations, shallow water, or floes, therefore adding or saving nautical miles or time per journey. Both of these main routes are open for a few months each year, in summer and early autumn. Even during this period, icebreaker escort may be required to safely cross (Overland and Wang 2013). 


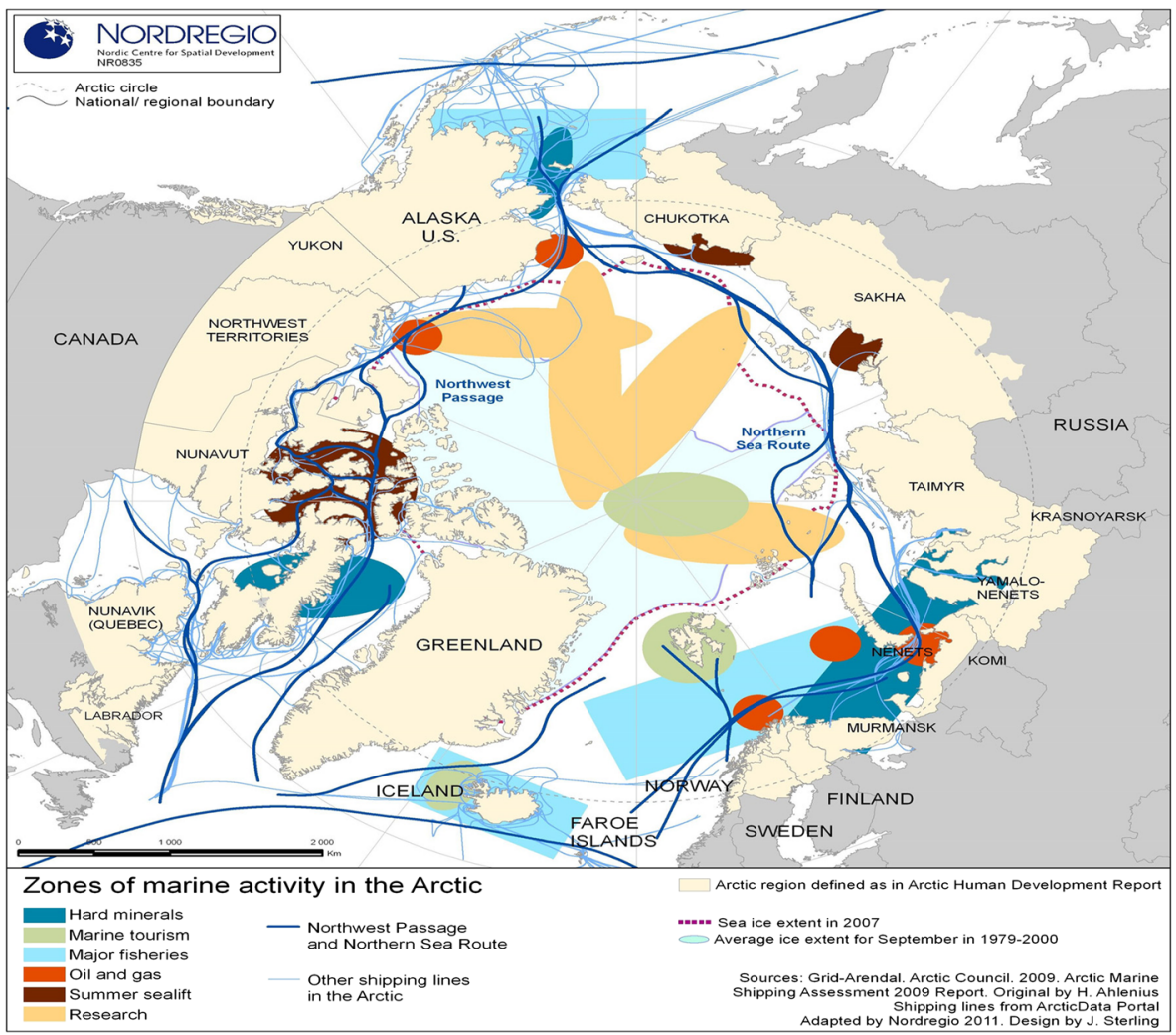

Fig. 1: "Arctic Passages" and zones of marine activity in the Arctic

Apart from the NEP/NSR and the NWP, the term Arctic Bridge (AB) describes a seasonal sea (and air) connection between the Canadian port of Churchill and the Norwegian port of Narvik - or the Russian port of Murmansk. For the time being, this route is only easily navigable about four months of the year, but it may become a more viable commercial option as the climate warms. For example, both Canada and Russia could benefit from using the Arctic Bridge: Russia could get easier access to North American markets, while Canada could use the Northern Sea Route (with Murmansk as an intermediate step) towards Asia. The concept of the Arctic Bridge with the respective hub located in the port of Churchill was proposed by the Canadians in the early 1990s. A protocol of intent on the establishment of a seaways trade route between Murmansk Oblast and the Province of Manitoba was signed in 2002, and the first shipment on the Arctic Bridge was conducted in October 2007, when the Murmansk Shipping Company's vessel Kapitan Sviridov transported nitrogen fertilizers to Churchill (Pettersen, 2011). In any case, it is possible to connect the northern territories of the Eurasian and the American continents (and markets) through this Arctic Passage. Finally, in case the extreme scenario of ice melting becomes a reality, the Central Arctic Route (CAR) or Transpolar Route (TPR) will provide the shortest route connecting Asia and Europe to the North American market; the discussion about NWP and NEP 
will then be rendered moot. A more realistic outlook is that the CAR is expected to be open only for summer months and most likely ice-capable vessels or icebreakers will remain essential to cross these waters.

The extremely high costs associated with building ice-reinforced vessels or the idea of retrofitting existing vessels to make them suitable for trans-Arctic shipping endeavors has in fact tempered investors' outlook on the viability of these abovementioned Arctic routes. Even the possibility of navigating via the central portion of the Arctic Ocean (CAR or TPR) is now under consideration. It is indicative to the fact that the September 2016 sea ice extent tied with 2007 for the second lowest Arctic sea ice minimum in the 37-year satellite record (NSIDC 2017). The notion of using Arctic Passages as viable alternatives for the traditional routes through the Suez or Panama canals is a strong motive; exploration and possible exploitation of resources are also part of the business opportunities equation in the High North. The attractiveness of these passages is heightened by the substantially shorter distance offered. For instance, the NSR is a substantially shorter passage (since it can offer 35 to $60 \%$ savings in the distance) for shipping between Northern Europe ports and those of the Far East and Alaska, when compared with the routes through the Suez or Panama canals (Arctic Council 2009). The NWP has the potential to function as an alternative to both canals, with an estimated reduction in distance between Northwestern Europe and Asia of $30 \%$, as well as up to $20 \%$ between New York (representing North American ports) and Yokohama (representing East Asian ports). However, the benefit of shorter navigational distances, thus lower operating costs, comes with a fair share of risks and uncertainty, particularly along the NWP, since the ice conditions in the Canadian Arctic are generally more severe than those along the NSR. Harsh conditions due to seasonality and shifting ice conditions even in the summer months, coupled with complex archipelago geography, draft restrictions, numerous choke points, and lack of reliable navigational aids and charts do not make this option terribly attractive as originally envisioned (Wilson et al. 2004). In any case, for the time being, both the NSR and NWP are only tentatively open August through October (up until the early part of this century), but certain research efforts via computer modeling indicate that these passages could be open even in November by midcentury.

\section{Northern Sea Route}

The NSR has attracted the most attention and traffic so far; it will be further examined in the current section. As previously mentioned, the NSR offers an alternative to the Suez Canal with indicative advantages including no congestion, no danger of piracy, and less nautical miles to travel (Dalaklis et al. 2016). Shipments transported via this route include fuel, timber, equipment, and various commodities; an important aim of the Russian state is to attract more cargo flows. For this reason, it has invested heavily in shipbuilding and projects so as to enhance support of navigation (for example, it has updated the respective nautical charts and already established operational the muchneeded search and rescue (SAR) centers), increased logistic support, and even put forward plans to establish a land network that will connect the NSR ports with other markets. In Russia, there is a constant effort to "boost" shipping operations via the Arctic; a characteristic initiative in this context, by the governor of the Arkhangelsk 
Oblast, is about the establishment of an institute that would coordinate logistics (joint operator) along the NSR when it comes to "transportation of supplies to state customers in the Arctic" aiming at the same time at the increase in benefits and reduction of respective expenses (Pettersen 2016). The designation of a few "special support zones" has also been suggested (by the Russian deputy prime minister) as a mean to facilitate and enhance the development of the Russian Arctic (Staalesen 2016).

It is important to highlight that according to political perception and legal regulations in Russia, the NSR stretches from Novaya Zemlya in the west (meridian $168^{\circ}$ and $37 \mathrm{~s}$ west) to the Bering Strait in the east (parallel $66^{\circ}$ north) (Østreng 2010). The establishment of the NSR was decided by the Council of People's Commissars of the USSR on the 17th of December 1932, which marks the beginning of the NSR as an administered, legal entity under full Soviet jurisdiction and control. It comprises the main part of the so-called Northeast Passage (NEP) which, with the addition of the waters of the Barents Sea, connects the Atlantic and Pacific Oceans along the entire length of the northern coast of the "Eurasia." 3 The NSR is not a specific route, but a multitude of passageways along the Russian Arctic coastline and therefore covers a vast segment of the Arctic Ocean (Kronbak and Liu 2010). Recent interest in the form of "traffic facilitated by climate change" started in 2009 when a complete transit was made possible for the first time, spurring the debate regarding the viability of the socalled Arctic Passages (Dalaklis and Baxevani 2016). It is indicative that interest has been expressed, although restrained for now, by Asian states to use the NSR. The economic partnership between Russia and China (highlighted by the Yamal project ${ }^{4}$ ) is clearly expected to generate additional maritime traffic in the years to come. ${ }^{5}$

The NSR is seen as the most viable route for servicing transport needs along the Russian Arctic coast. Discussions are also focused on taking advantage of the NSR as a connection corridor for the shipment of goods between Europe and East Asia (trans-Arctic voyages); vast quantities of proven oil, gas, and mineral reserves are also situated along this route. While the possibility of resource extraction and transport along the NSR captured the keen

\footnotetext{
${ }^{3}$ The Barents Sea is bordered by the Norwegian Sea in the west, the islands of Svalbard (Norway) in the northwest, and the islands of Franz Josef Land and Novaya Zemlya in the northeast and east; Novaya Zemlya separates the Kara Sea from the Barents Sea. It is also important to note that the southern half of the Barents Sea remains ice-free year-round due to the warmth brought by the North Atlantic drift, clearly limiting the need for icebreakers support there. This includes the ports of Murmansk in Russia and Vardø in Norway.

${ }^{4}$ Launched at end of 2013, this is one of the most complex liquefied natural gas (LNG) projects ever undertaken; Yamal is located "above" the Arctic Circle and in a region that is ice-bound for seven to nine months during the year and completely isolated from the necessary logistics support infrastructure. LNG tankers with icebreaking capabilities (along the NSR), specially designed for the project, will ship the precious cargo to the respective international markets. Available online: < http://www.total.com/en/energyexpertise/projects/oil-gas/lng/yamal-lng-cold-environment-gas $>$.

${ }^{5}$ It is indicative that on the 6th of June 2017, Russia's President Vladimir Putin, South Korea's Ambassador to Russia Park Dae-Bong and Daewoo Shipbuilding \& Marine Engineering Co. (DSME) CEO Jung Sung-Leep attended the naming ceremony of the world's first icebreaking liquefied natural gas (LNG) carrier "Christophe de Margerie" in St. Petersburg. The ship will be deployed for Russia's national Far East resource development on the Yamal Peninsula, in the western part of Siberia. The icebreaking-capable LNG carrier, $299 \mathrm{~m}$ long and $50 \mathrm{~m}$ wide, can carry 173,600 cubic meters of LNG. The icebreaking Arc-7 ice class carrier, capable of sailing through 2.1-m-thick ice, is made of special steel plate, three times thicker than typical plates. DSME received an order for 15 icebreaking LNG carriers from companies in Russia, Japan, and Canada for roughly $\$ 14.8$ billion (at \$320 million per ship). The remaining 14 carriers are being constructed at the Okpo shipyard in Geoje, South Gyeongsang Province, and are expected to be delivered by the first half of 2020. Available online: https://www.marinelink.com/news/icebreaking-carrier426018\#.WTVvqBZ3j-w.linkedin.
} 
interest of investors, vessel transit numbers have dwindled in recent years. According to the NSR Information Office, just four ships navigated this route in 2010, increasing to 41 in 2011 and 46 in 2012. By 2013, the number rose to 71, followed by a significant drop to 31 in 2014 and 18 in 2015. Despite record low minimum ice coverage in 2016, just 19 vessels transited this route moving a total of 214,513 metric tons (mt) of cargo and 246 passengers (Northern Sea Route Information Office 2017). On the positive side, Russian investments are ongoing to enhance logistics and hinterland connections and establish a land network between Asian and European markets. However, there is still a large gap in properly trained crews for Arctic conditions and a reliable marine traffic system to improve monitoring and tracking of marine activity, as well as augment vessel management services to reduce the risk of incidents, facilitate response, and provide awareness of potential user conflict. The infrastructure deficit includes a lack of navigational charts, ice navigation training, places of refuge, and robust centers with port services capable of providing reception facilities for ship-generated waste. Furthermore, with the majority of transits along the NSR comprised of tanker vessels (Fig. 2), the prospect of inadequate emergency management resources to respond to oil or chemical discharges is an additional deterrent; therefore, intensive preparatory measures in relation to oil spill response are needed and for the time being, this route should not be considered as a very compelling alternative to the proven routes of the Indian Ocean and the Suez Canal.

\section{Search and rescue infrastructure along the NEP/NSR}

Shipping companies attracted by the abovementioned operating cost-savings (shorter voyager, less fuel consumption, etc.) and all other benefits associated with these "Arctic

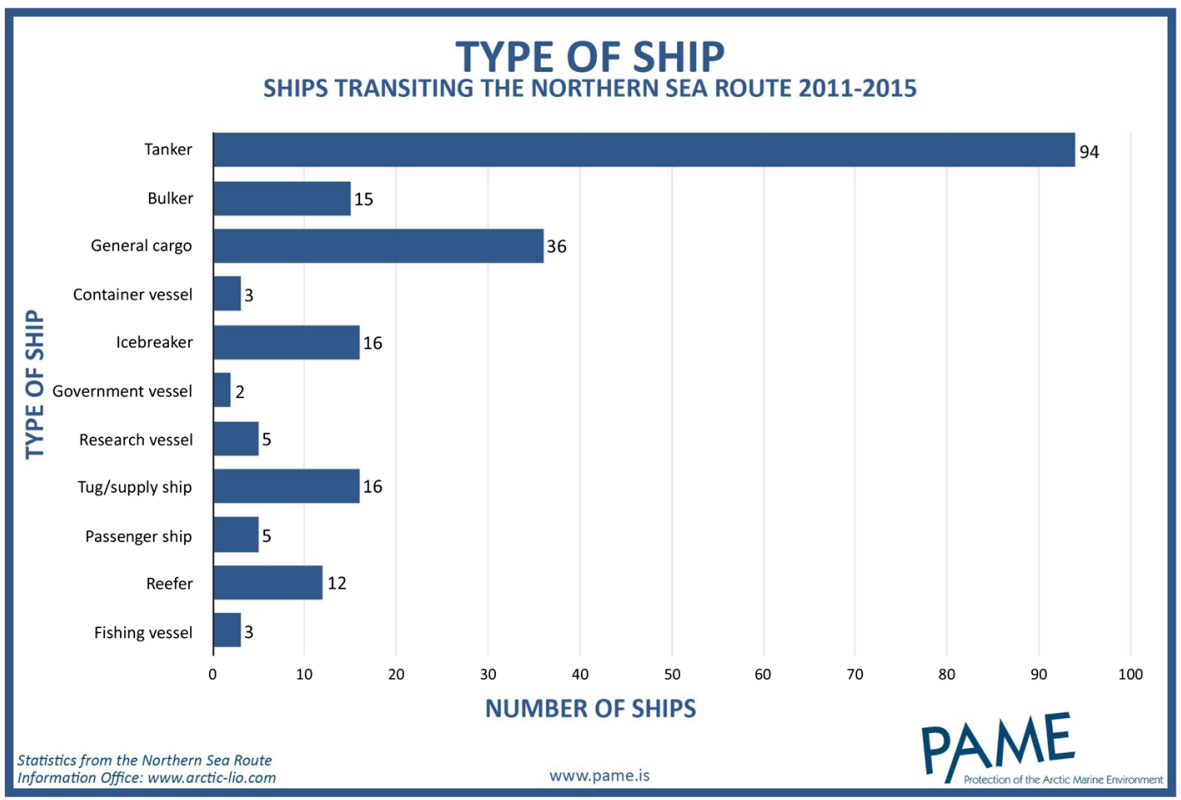

Fig. 2 Types of ships transiting the Northern Sea Route from 2011 to 2015. Source: Northern Sea Route Information Office 2017, available online: <http://www.arctic-lio.com/nsr_transits> 
Passages," as well as those countries motivated by political ambitions to carve out a place for themselves in the Arctic, have not fully analyzed the full spectrum of implications in relation to human activities in the High North and especially how the limited rescue resources, challenging weather conditions, and remoteness of the area can impact the ability to render SAR assistance adequately and in a timely manner. The current section will focus on emergency management capabilities to include the current state of rescue coordination centres, search and rescue assets, oil spill response equipment, and icebreaker ${ }^{6}$ availability with emphasis on the NEP/NSR. Even though environmental data supports an Arctic with "a lesser ice status," it is of importance to understand that despite the trend of rapidly declining ice coverage, at certain geographic locations, sea ice can still grow in thickness (Hodges 2015). In fact, when gauging how permissible are the overall conditions for sea travel, ice thickness is the most important criterion. It is certainly true that ice coverage is retreating, but it can be nearly impossible for ships to make their way through the remaining ice if it is still too thick (Dewitz et al. 2015). As the waters of the Arctic will be more approachable in the near future, shipping traffic will increase, and those ships will be exposed to certain risks. Therefore, while the reduction of ice coverage in this region may signal the need for fewer icebreakers, the growth in shipping traffic and unpredictable environment require nations to bolster their icebreaking fleet. Icebreakers are the foundation of any capability in the Arctic and serve as excellent multifunctional platforms for numerous purposes to include search and rescue, resupplying remote Arctic communities and ensuring shipping traffic channels remain ice-free, research, and drilling. Therefore, it is imperative that additional investments are made in icebreakers to facilitate shipping along both the NSR and NWP. However, it is essential to point out that for the time being, the Russian icebreaking capabilities far exceed those along the NWP.

Actions taken by the Arctic Council (AC) in recent years to allocate SAR resources on an international level have successfully streamlined new policies and bipartisan agreements to improve maritime safety and environmental protection in the Arctic region. In 2011, eight Member States of the Arctic Council signed an Agreement of "Cooperation on Aeronautical and Maritime SAR" in the Arctic. Specifically, this legal instrument coordinates life-saving international maritime and aeronautical SAR coverage (Fig. 3) and response among the Arctic States across an area of approximately 13 million square miles (U.S. Department of State-International Security Advisory Board 2016). Furthermore, the agreement established competent authorities for each of the eight member states and agencies responsible for carrying our SAR activities and lists the rescue coordination centres (RCC) by name and location for each member state. Unfortunately, this agreement is not prescriptive in the manner by which member states much physically implement a response posture and is, therefore, a bit "clouded." To provide some direction of the response to potential oil spills in the Arctic region, the Arctic Council facilitated the signed Agreement on Cooperation on Marine Oil Pollution Preparedness and Response in the Arctic in 2013. The objective of this agreement is to strengthen cooperation, coordination, and mutual assistance among the parties on

\footnotetext{
${ }^{6}$ An icebreaker is a special-purpose vessel. It is designed to move and navigate through ice-covered waters; its main purpose is to provide safe waterways for other ships. For a ship to be considered an icebreaker, it requires three traits that most normal ships lack: a) a strengthened hull; b) an ice-clearing shape; c) the power to push through sea ice (Dalaklis and Drewniak 2017). An icebreaker capable ship clear paths by pushing straight into ice pockets; it can also drive its bow onto the ice to break it under the weight of the ship.
} 


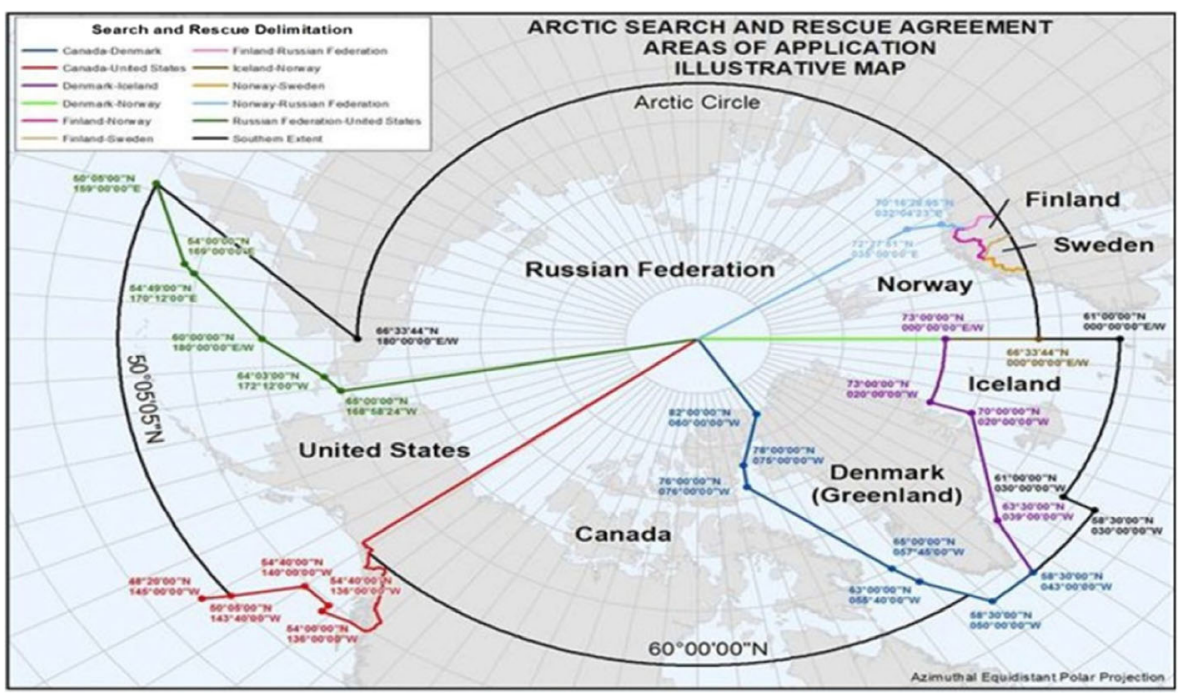

Fig. 3 Arctic search and rescue agreement - areas of application. Source: Northern Sea Route Information Office 2017, available online: <http://www.arctic-lio.com/nsr_searchandrescue>

oil pollution preparedness and response in the Arctic to protect the marine environment from pollution by oil. However, Arctic nations such as Russia, Norway, Canada, ${ }^{7}$ and the $\mathrm{USA}^{8}$ must build up more supporting infrastructure and port capabilities to attract

\footnotetext{
${ }^{7}$ Compared to the Russian Arctic, the NWP is extremely underdeveloped, especially around the waterways of the Canadian Arctic. There are no adequate deep-water ports along the northern slope of Alaska or throughout the NWP (Eger 2010). Port facilities along the North American Arctic coast west of the passages are equally negligible, and the closest well-developed infrastructure is the west coast of Greenland, Nuuk, being the largest and most significant port. Shipping in the Canadian Arctic is governed by the 2001, Canada Shipping Act. This Act established a framework for SAR and communication operations in Canadian Arctic waters and included the following services in the Arctic: monitoring international marine radio distress frequencies, broadcasting ice and marine weather information and notices concerning hazards to navigation, and screening ships entering Arctic waters to enhance safety and prevent pollution. A party to the Arctic 2011 SAR Agreement, The Canadian Minister of National Defense, is designated as the Competent Authority in the Arctic Council's 2011 SAR Agreement, and both the Canadian Coast Guard (CCG) and Canadian Forces are designed as SAR agencies. Furthermore, the designated rescue coordination centre for Canada is located in Trenton, and the respective SAR area of responsibility is provided via Fig. 3.

${ }^{8}$ Waters around Alaska fall under US jurisdiction and are governed by the U.S. Coast Guard (USCG) which is fundamentally responsible for maritime safety, national defense, maritime security, maritime mobility, protection of natural resources, and ice operations. As the lead agency for maritime SAR, the USCG maintains a coastal network of boat stations, aircraft, communication systems, and a command-and-control network to respond to those in peril at sea. The USCG is designated as the Competent Authority in the Arctic Council's 2011 SAR Agreement and both the USCG and U.S. Department of Defense are designated in that legal instrument as SAR agencies. The designated joint rescue coordination centre (JRCC) for the USA is located in Juneau, and an Aviation Rescue Coordination Centre is located in Elmendorf, outside Anchorage, Alaska; the SAR area of responsibility for the USA is also designated in Fig. 3. Given the instrumental role the USCG plays in maritime operations within Arctic waters, there are multiple capital investments needs in infrastructure to include icebreaking capabilities and the shore-based infrastructure to support both SAR and icebreaker operations. Specifically, the USCG has inadequate force structure to meet SAR contingencies and investment in constructing ice-strengthened patrol ships and aircraft for extreme climates is needed. Furthermore, as vessel traffic is expected to increase in the Arctic region, the USA needs to invest in pollution response capabilities and sufficient infrastructure to support safe and secure maritime commerce. See also Deboer (2017), Arctic Security and Legal Issues in the 21st Century: An Interview with CDR Fahey, available online: http://cimsec. org/arctic-security-legal-issues-21st-century-interview-cdr-sean-fahey/31016.
} 
maritime shippers along the NEP/NSR and NWP; development of international contingency plans to prepare for increased shipping traffic and the possibility of large-scale maritime accidents that require SAR and oil spill response is also essential.

The NEP/NSR is for the time being considered as the preferred passage through the Arctic region. However, the specific route involves many challenges that temper optimism of serving as a suitable alternative to the Suez Canal, such as shallow waters limit ship size; lack of modern deep-water ports and very restricted SAR capabilities that require crossing ships to have very high standards of autonomy and safety; harsh weather conditions and free-floating ice make navigation more difficult and schedules more variable. Finally, more expensive ship construction and operation costs lessen the economic viability of this route. Per the Arctic Council's 2011 SAR Agreement, the Russian Federation is responsible for the SAR mission along the NSR. To address concerns associated with the safe transit of vessels along this portion of the NEP, Russia has invested 910 million rubles (\$30.1 million) into the creation of ten SAR centers along the NSR (Murmansk, Dikson, Arkhangelsk, Naryan-Mar, Vorkuta, Nadym, Tiksi, Pevek, Provideniya, and Anadyr) (Farré et al. 2014).

Oversight of SAR and oil spill response along the NSR is coordinated by two different marine rescue operations headquarters (splitting the area of responsibilities in an eastern and western sector respectively), along with the support of two marine rescue coordination centres (MRCCs) and four marine rescue sub-centres (MRSCs). The two MRCCs are located in Murmansk and Dikson, while the MRSCs are located in Archangelsk, Tiksi, Pevek, and Provideniya (Figs. 4 and 5). The NSR Information Office also communicates the availability of five icebreakers (NS Yaygach, NS Yamal, NS 50 Let Pobedy, NS Taimyr, and Admiral Makarov), two of which also have dive equipment and oil spill response equipment, capable of providing icebreaker support for vessels in the NSR. Despite these proactive measures to lessen the risk associated with traveling the NSR and the increased SAR posture, these centers and sub-centers are still separated by very vast distances and the response time may easily be inadequate to prevent fatalities in case of an emergency (Hansen et al.,2016). However,

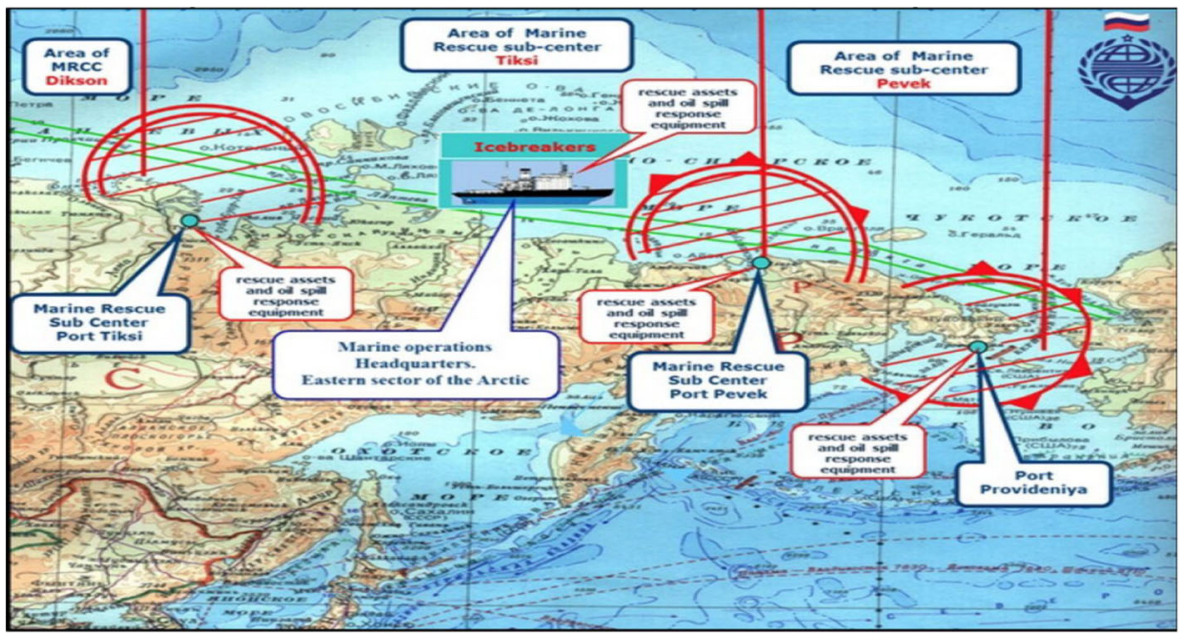

Fig. 4 Rescue coordination centres and sub-centres along the NSR. Source: Northern Sea Route Information Office 2017, available online: <http://www.arctic-lio.com/nsr_searchandrescue> 


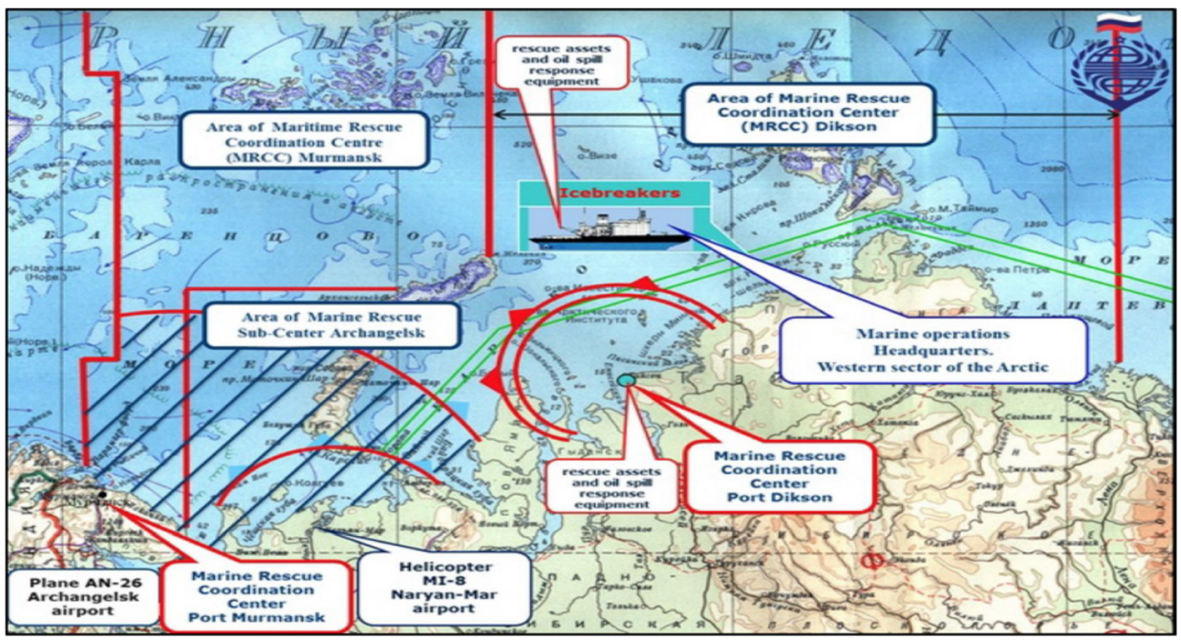

Fig. 5 Rescue coordination centres and sub-centres along the NSR. Source: Northern Sea Route Information Office 2017, available online: <http://www.arctic-lio.com/nsr_searchandrescue>

Russia continues to make a significant investment in icebreaking capabilities along the NSR to include ambitious plans to commission three new-nuclear-powered icebreakers (Arktika, Sibir, and Ural) of the Project 22220 (LK-60Ya class). Finally, the availability of the Arc7 ice-classed LNG carriers capable of breaking through $2.1 \mathrm{~m}$ of ice (to serve the Yamal project) is also welcomed, since it will increase the number of vessels transiting the NSR and could provide a helping hand in time of need. However, their main mission will be to cover transport needs, unlike the previous listed icebreaking vessels that their primary mission is supporting shipping operations and being involved in emergency management situations.

More importantly, Russia is the only country to already have nuclear-powered icebreaking vessels in service (Domonoske 2016); this type of propulsion practically removes the need of refueling and greatly increases the range of operation, something extremely important to effectively deal with the vast distances of the Arctic Ocean. Currently, there are six nuclear-powered icebreakers in service (Rossiya, Vaigash, Taimyr, Yamal, 50 Let Pobedy, and Sevmorput) with ambitious plans to commission three new icebreakers (Arktika, Sibir, and Ural) of the Project 22220 (LK-60 class) between 2018 and 2020 (Nilsen 2016). Arktika, the largest nuclear-powered icebreaker ever build, is valued at $\$ 1.2$ billion and, with 80,000 horsepower (hp), will break up ice up to 10 - $\mathrm{ft}$ thick. Impressively, the vessel under discussion was launched from JSC Admiralty Shipyards in St. Petersburg on June 10, 2016, a year ahead of schedule. It has an anticipated commission date of December 2019 (Lakshni, 2016). For reason of clarity, the complete breakdown of the Russian nuclear-powered icebreakers' fleet is presented in Fig. 6.

Interestingly enough, the Russian State has a large variety of icebreaking capable vessels. It is indicative that during the implementation of the Federal Target Program, Development of Transport System of Russia (2010-2015), the construction of six modern response vessels was included. Specifically, these multifunctional rescue vessels are part of the projects MPSV06 and MPSV07. The MPSV06 class averages $86 \mathrm{~m}$ in length (282 ft) by $19.1 \mathrm{~m}$ (63 ft). The first of its class, Spasatel Petr Gruzinskiy, 


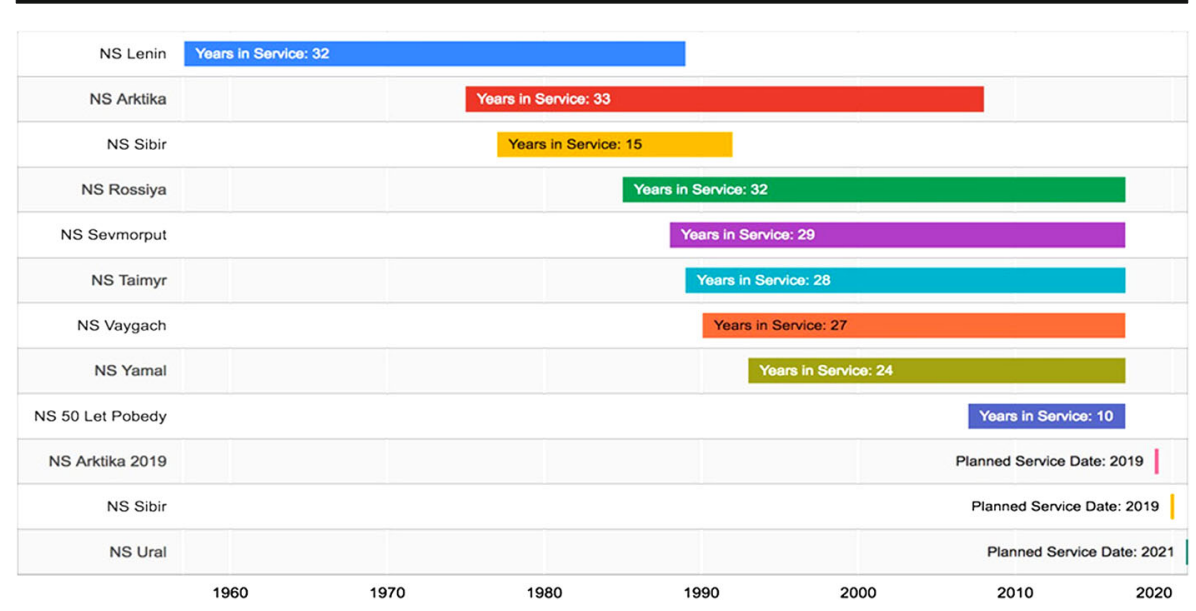

Fig. 6 Russian nuclear-powered icebreakers. Source: Drewniak et al. 2017

is currently being built at a Russian facility on the Amur River, while a German yard has already completed two sister ships, Beringov Proliv and Murman. These two vessels each weigh 1370 dead weight tons (dwt) and are furnished with two large cranes for salvage capabilities as well as a forward mounted landing platform for helicopters (Shaw 2016). Additionally, they possess the capability of maneuvering a remotely operated underwater vehicle and possess decompression facilities for deep water diver use. ${ }^{9}$ The clear conclusion is that Russia has significantly invested in building icebreakers; the country leads the way and has a "toolbox" available to support (up to a certain level) shipping operations in the NSR, with more capabilities already lined up. It is a self-explanatory fact that the intensification of SAR capabilities along the NSR increases operational awareness and support Arctic petroleum development in the face of declining production in the already rather mature West Siberian oilfields (Stephenson and Smith 2015). Furthermore, new Arctic Council observer States like China, Korea, and Japan are supporting the further development of the NSR through shipbuilding and scientific research to secure alternative sources and supply lines of energy (Bennett 2014). Therefore, the current Russian icebreaking capabilities, coupled with the future outlook of expanding the already robust fleet, make the NSR a very promising option. Off course, caution is needed: a rapid increase in crossing traffic should be swiftly balanced by the relevant increase in the allocated resource for emergency management.

Moving westwards and in continuity of the Russian SAR area of responsibility, there is the respective Norwegian one. The joint rescue coordination centre of Northern Norway ( $\mathrm{NRCC} \mathrm{NN}$ ) is a rescue coordination centre located in Bodo. It has the responsibility for coordinating SAR operations in Norway, north of the 65th parallel (Hovedredningssentralen, 2017). Unfortunately, resources to support the NSR from the Norwegian side are lacking; however, it is positive to note that Norway and the Russian

\footnotetext{
9 The Russians have also produced four vessels in the slightly smaller MPSV07 class that have all entered into use, following their completion in 2015 (Spasatel Karev, Spasatel Kavdeykin, Spasatel Zaborschikov, and Spasatel Demidov). The characteristics of this class are approximately $1171 \mathrm{dwt}$ vessels measuring $73 \mathrm{~m}$ by $16.6 \mathrm{~m}$. Their capabilities include the ability to stay at sea for roughly 20 days and can support underwater diving operations down to depths of $300 \mathrm{~m}$ (Dalaklis and Drewniak 2017).
} 
Federation have a bilateral search and rescue agreement for the Barents Sea of which the content pertained in this agreement is exercised annually. Furthermore, there are informal search and rescue arrangements with local governmental and private entities, but they fall outside the scope of the analysis in hand. In any case, it is important to consider that the coastal areas of Norway remain relatively ice-free as a result of the Gulf Stream (leaving northern Norway ports ice-free year-round). Therefore, Norway does not have a compelling reason to build up a large fleet of icebreaking vessels. As such, Norway maintains only one active offshore patrol icebreaking vessel (Svalbard), commissioned on 17 February 2001. Svalbard is the largest ship in Norway's military armed forces (by tonnage), designed to supplement the three other helicopter-carrying ships of the Norwegian Coast Guard. The vessel is nuclear, biological, and chemical (NBC) and is protected with a constant overpressure and is capable of icebreaking and emergency towing up to 100,000 tons. There is more positive news: Norway has plans for a new icebreaker research vessel, Kronprins Haakon, scheduled for delivery in the near future (end of 2017/2018). This new state-of-the-art vessel will be formally owned by the Norwegian Polar Institute, the Institute of Marine Research will have operational responsibility, and the University of Tromsø will be the primary user. In addition to possessing renowned scientific instrumentation, the vessel will operate year-round in ice-covered waters with an endurance capacity of 65 days at cruising speed (Your Subsea News 2017).

\section{Conclusion}

The High North is seen as a place defined by constant change and uncertainty; the most northern and frozen part of the Earth was never before integrated into regular shipping routes due to the very harsh environmental conditions. However, the continuous decline of ice coverage in the wider region has triggered an interest towards the establishment of "Arctic liner shipping". Northern ports such as Murmansk, Archangelsk, Dikson, Dudinka, Tiksi, Vladivostok, Pevek (Russia), and Narvik, Tromsø (Norway), as well as Barrow, Prudhoe Bay (USA), Inuvik, and Churchill (Canada), can benefit from this momentum. It is no coincidence that both the USA and Russia are keeping an open eye on the new shipping routes created in the melting Arctic. Political and military leaders in Washington, D.C., are already pointing to a crucial gap in the "right" type of vessel that can turn frozen waters into reliable lanes for commerce or national defense. Icebreakers will be increasingly needed to smash through sea ice, open routes, or assist trapped vessels. Russia has a strong advantage both due to the number and autonomy of its icebreaking fleet, whereas the USA icebreaking fleet is comprised of only two operational vessels. ${ }^{10}$ It is obvious that Russia has certain Arctic aspirations and has already invested a great effort into establishing some of the necessary icebreakers' support, as well as ports and hinterland networks to accommodate both commercial activities and energy production needs. An indication of the aspiring traffic for the NSR

\footnotetext{
${ }^{10}$ Research for the availability of icebreakers for both Canada and the USA is ongoing, but related details fall out of the scope of the current analysis. More details of the findings will be communicated shortly (Drewniak M. and Dalaklis D. (tbp 2018), "Expansion of Business Activities in the Arctic: The Issue of Search and Rescue Services," Ocean Yearbook 32).
} 
is the construction of new ports (for instance, the Sabetta one, as a necessity for the Yamal project). This is also a project where one of the world's most rapidly developing economies, China, is a partner. A new partnership is clearly in place, highlighting very close relations between these two States.

The clear conclusion is that Russia has significantly invested in building icebreakers and its current number of vessels available is certainly able to easily handle the current level of traffic; the country leads the way in this type of shipbuilding activity and has a "toolbox" available to support (up to a certain level) shipping operations in the NSR, with more capabilities already lined up. On the other hand, ensuring at all times the safety of an increased number of vessels crossing the NSR certainly translates into more investments; the projected availability of the limited number of five to six vessels is certainly not enough to spread around the full length of the NSR and cover each and every aspect of looming danger. Furthermore, it was already pointed out there is still a large gap in properly trained crews for Arctic conditions and that the lack of a reliable marine traffic system to improve monitoring and tracking of marine activity, as well as augment vessel management services to reduce the risk of incidents, facilitate response, and provide awareness of potential user conflict, is standing out. There are also other gaps in the necessary support of shipping operations in the Arctic: The infrastructure deficit includes a lack of navigational charts (although an effort of update/improvement has already started). Furthermore, some aspects of available regulation need to be more detailed; for example, establishment and communication to those interested parties of places of refuge in the NSR is still pending. The creation of robust centers along this route with port services capable of providing reception facilities for ship-generated waste should also be considered. Continuing upon the regulatory aspect, the "search and rescue" (SAR) instrument is a very encouraging cornerstone; implementation of the necessary details and pooling of capabilities together will be essential for dealing with the vast distances/areas to be covered. ${ }^{11}$

After examining the current state of the icebreaker fleet along the NSR, including projections for the near future, there is still an important question to investigate further: Is the Russian economic investment in the Arctic region going to pay off? The country is supporting its Arctic's endeavors with a plethora of ice-capable vessels already operational and with a very clear strategy for the future. Russians have used their previous experience and lessons learned for ship type best poised to operate in the Arctic region; they have stated political goals and ambitions and committed a vast amount of invested capital and resources to develop the Arctic area ahead of any other country. However, these economic investments come as Russia is faced with many setbacks that dampen their hopes of expanding Russian sovereignty and shake the

\footnotetext{
${ }^{11}$ Another extremely beneficial regulatory effort was the introduction by the International Maritime Organization (IMO) of the International Code for Ships Operating in Polar Waters (Polar Code-PCD) that entered into force on January 1, 2017. The Polar Code (PCD) was introduced as an amended the International Convention on the Safety of Life at Sea (SOLAS), but it is important to note that this Code is only applicable to vessels of 500 gross tons or more. Critics are calling on regulators to examine the gaps in the PCD regarding the applicability of vessels based on size. This distinction is important because the regulations do not apply to vessels of less than 500 gross tons (such as fishing boats, private yachts, and eco-tourism vessels) of which a majority of the current vessel traffic in the Arctic region is comprised. Suggestions for more regulation have also been put forward, like limiting the use of marine fuel oil in the wider region. It is noteworthy that the current regulatory framework concerning the Arctic does not ban the use of heavy fuel oil (HFO), nor does it exclude ships from carrying bunker fuel as cargo.
} 
foundation of their "grand Arctic plans." Furthermore, USA and EU sanctions have made it tough for the Russian state-owned oil company, Rosneft, to continue Arctic exploration without the backing of large US and European oil companies. However, Russia has opted to forge ahead fueled by the desire to further their geopolitical agenda, fight severe unemployment in its Arctic regions, and refine certain technological advances. In any case, should the NSR become fully integrated in the global maritime transport system, Russia's geopolitical status will be clearly improved and further research is needed to discuss the implications both at the regional and global levels.

Summing up, the sectors of transport, natural resource extraction, fishing, tourism, energy production, and various others constitute the reasons the Arctic is going to receive increased maritime traffic in the future. To reap only benefits and avoid a natural disaster, there is the need of strengthening available support; icebreakers provide the "ideal platform" to this end. Especially for the NSR that was examined in the current analysis, current availability of icebreakers is adequate to handle the limited level of traffic. However, if traffic is increased, additional measures of support should also be introduced. Finally, it is true that very low temperatures and ice are major hindrances when it comes to shipping operations in the Arctic; availability of icebreakers is now and will continue to be in the future essential to maintain a clear path for ships traveling along the NSR. However, in order to navigate safely in the Arctic Ocean, there is a need for more (appropriate) infrastructure support and trained personnel who are clearly capable of safely operating their vessel in these truly harsh and very icy conditions. This can be achieved only via tailor-made training courses and accumulating practical experience in these unfriendly waters; the issue of relevant simulation training for Arctic conditions should also be researched further. Last but not least, the huge challenges of the Arctic in terms of distance/area to be covered call for a timely and coordinated response; any SAR incident in the Arctic will probably be of international nature dictating that SAR training courses and even conduct of the respective exercises and live drills are actions of priority. The planning and materialization of realistic exercises (with as many as possible stakeholders involved) to include the issue of mass rescue operations, now that touristic activities are on the rise, is standing out.

Acknowledgments The current research was conducted under the MARPART-2 MAN and MARECSAMRISK Projects. The views herein are solely of the authors and do not represent the views of the United Nations/World Maritime University, or the Department of Homeland Security/US Coast-Guard, or any other organization with a similar scope.

\section{References}

Arctic Council (2009) Arctic Marine Shipping Assessment 2009 Report, available online: www.pmel.noaa. gov/arctic-zone/detect/documents/AMSA_2009_Report_2nd_print.pdf

Barnhart KR, Miller CR, Overeem I, Kay JE (2015) Mapping the future expansion of Arctic open water. Nat Clim Chang 6:280-285. https://doi.org/10.1038/nclimate2848

Bennett MM (2014) North by Northeast: toward an Asian-Arctic region, available online: http:/www. tandfonline.com/doi/abs/10.1080/15387216.2014.936480 
Borsch OJ, Andreassen N, Marchenko N, Ingimundarson V, Gunnarsdottir H, Ludin L, Petrov S, Jacobsen U, and Dali BI (2016) Maritime activity in the High North-current and estimated level up to 2025. MARPART Project Report 1, Nord Universitet, Bodo, 2016

Cariou P, Faury O (2015) Relevance of the Northern Sea Route (NSR) for bulk shipping. Transp Res A 78: 337-346

Climate NASA (2016) Climate trends continue to break records, available online: https://www.nasa. gov/feature/goddard/2016/climate-trends-continue-to-break-records

Dalaklis D, Baxevani E (2016) Arctic in the global warming phenomenon era: new maritime routes and geopolitical tensions. In: Delfour-Samama d'O, Leboeuf C, de Gwenaele P-M (eds) New maritime routes: origins, evolution and prospects. A. Pedone, Paris

Dalaklis D, Baxevani E (2017) Maritime routes in the Arctic: examining the level of traffic and port capabilities along the Northern Sea Route. In: Chircop A, Coffen-Smout S, McConnell M (eds) Oceans' Yearbook 31. Brill Nijhoff, Leiden, pp 06-35. https://doi.org/10.1163/9789004347137_006

Dalaklis D and Drewniak M (2017) The Arctic region: mapping the current state of icebreakers \& identifying future trends, (presentation) Maritime Search \& Rescue 2017 conference, Helsinki-Finland, 24 May 2017. https://doi.org/10.13140/RG.2.2.19287.88481

Dalaklis D, Baxevani E and Siousiouras P (2016) The future of Arctic shipping business and the positive influence of the Polar Code, International Association of Maritime Economists 2016 Conference, Hamburg-Germany, August 24, 2016

Deboer S (2017) Arctic security and legal issues in the 21st century: an interview with CDR Fahey, available online: http://cimsec.org/arctic-security-legal-issues-21st-century-interview-cdr-sean-fahey/31016

Dewitz J, Dalaklis D, Olcer A, and Balini F (2015) Arctic LNG: exploring the benefits of alternative fuels to mitigate environmental impact risks, presentation in the conference: ShipArc 2015: Safe and Sustainable Shipping in a Changing Arctic Environment (World Maritime University), Malmo, Sweden

Domonoske C (2016) Russia launches world's biggest, most powerful icebreaker, available online: http:/www.npr.org/sections/thetwo-way/2016/06/16/482288188/russia-launches-worlds-biggest-mostpowerful-icebreaker

Drewniak M, Dalaklis D (2018) Expansion of business activities in the Arctic: the issue of search and rescue services. In: Chircop A, Coffen-Smout S, McConnell M (eds) Ocean Yearbook 32. Brill Nijhoff, Leiden

Drewniak M, Dalaklis D, Kitada M, Ölçer A and Ballini F (2017) Geopolitical considerations of shipping operations in the Arctic: mapping the current state of icebreakers and identifying future needs, International Association of Maritime Economists 2017 Conference, Kyoto-Japan, June 27-30, 2017. https://doi.org/10.13140/RG.2.2.17458.09921

Eger KM (2010) Canadian ports on the Northwest Passage, CHNL, available online: <http://www.arctissearch.com/Canadian+Ports+on+the+Northwest+Passage>

Eguíluz VM, Fernández-Gracia J, Irigoien X, Duarte CM (2016) A quantitative assessment of Arctic shipping in 2010-2014. Sci Rep 6:30,682 available online: http://www.nature.com/articles/srep30682

Farré AB, Stephenson SR, Chen L, Czub M, Dai Y, Demchev D, Efimov Y, Graczyk P, Grythe H, Keil K, Kivekäs N, Kumar N, Liu N, Matelenok I, Myksvoll M, O'Leary D, Olsen J, Sachin Pavithran AP, Petersen E, Raspotnik A, Ryzhov I, Solski J, Suo L, Troein C, Valeeva V, van Rijckevorsel J, Wighting J (2014) Commercial Arctic shipping through the Northeast Passage: routes, resources, governance, technology, and infrastructure. Polar Geogr 37:4, 298-4, 324. https://doi.org/10.1080/1088937 X.2014.965769

Funkdec McK (2014) The Wreck of the Kulluk. The New York Times, available online: http://nytimes. com/2015/01/04/magazine/the-wreck-of-the-kulluk.html?emc=edit_tnt_20141230\&nlid $=64813105$ \&tntemail0=y\&_r=0

Hansen Ø, Grønsedt P, Graversen L and Hendriksen C (2016) Arctic shipping-commercial opportunities and challenges, available online: http://www.cbs.dk/en/knowledge-society/business-in-society/cbsmaritime/downloads

Hodges P (2015) Study: Arctic Sea ice too thick for icebreakers, available online: http://astresistance. com/study-arctic-sea-ice-too-thick-for-icebreakers/

Kronbak J, Liu M (2010) The potential economic viability of using the Northern Sea Route (NSR) as an alternative route between Asia and Europe. J Transp Geogr 18(3):434-444

Marsh WM, Kaufman MM (2012) Physical geography: great systems and global environments. Cambridge University Press, Cambridge

Moe A (2014) The Northern Sea Route: smooth sailing ahead? Strateg Anal 38(6):784-802. https://doi. org/10.1080/09700161.2014.952940

Nilsen T (2016) Announces tender for fantasy giant icebreakers, available online: https://thebarentsobserver. com/en/arctic/2016/09/announces-tender-fantasy-giant-icebreakers 
Northern Sea Route Information Office (2017) available online: http://www.arctic-lio.com/nsr_transits

NSIDC, National Snow and Ice Data Center (2017) Low sea ice extent continues in both poles. January 5 , 2017, available online: http://nsidc.org/arcticseaicenews/2017/01/

Østreng W (2010) The northeast passage and northern sea route, available online: http://www.arctis-search. $\mathrm{com} /$ The+Northeast+Passage+and+Northern+Sea+Route+2

Overland JE, Wang M (2013) When will the summer Arctic be nearly sea ice free? Geophys Res Lett 40: 2097-2101. https://doi.org/10.1002/grl.50316

Pettersen T (2011) Russia to have ten Arctic rescue centers by 2015, Barents Observer, 18.11.2011. http://barentsobserver.com/en/topics/russia-have-ten-arctic-rescue-centers-2015. Accessed 8 Aug 2014

Pettersen T (2016) Proposes center for supply and logistics in the Arctic, available online: http://www. thebarentsobserver.com/arctic/2016/03/proposes-center-supply-and-logistics-arctic

Richter-Menge J, Overland JE and Mathis JT (2016) Arctic Report Card 2016, available online: http://www. arctic.noaa.gov/Report-Card

Shaw J (2016) Icebreakers—expanding the world's fleet, Volume 32, No 02, available online: http://www. pacmar.com/story/2016/02/01/features/icebreakers-expanding-the-worlds-fleet/408.html

Staalesen A (2016) Government outlines Arctic priority zones, available online: http://www. thebarentsobserver.com/arctic/2016/03/government-outlines-arctic-priority-zones

Stephenson SR, Smith LC (2015) Influence of climate model variability on projected Arctic shipping futures. Earth's Future 3:331-343. https://doi.org/10.1002/2015EF000317

U.S. Department of State-International Security Advisory Board (2016) Report on Arctic policy, available online: https://state.gov/documents/organization/262585.pdf

United Nations Conference on Trade and Development (UNCTAD) (2016) Review of maritime transport, (Series). available online: http://unctad.org/en/pages/publications/Review-of-Maritime-Transport-(Series). aspx

Wilson KJ, Falkingham J, Melling H, and De Abreu R (2004) Shipping in the Canadian Arctic-other possible climate change scenarios, available online: http:/www.pmel.noaa.gov/arctic-zone/detect/humanaccess-canada.shtml

www.marinelink.com/news/icebreaking-carrier426018\#.WTVvqBZ3j-w.linkedin

www.total.com/en/energy-expertise/projects/oil-gas/lng/yamal-lng-cold-environment-gas

Your Subsea News (2017) Fincantieri: Kronprins Haakon launched in Muggiano, available online: http://www.yoursubseanews.com/fincantieri $\% 3 \mathrm{~A}+\%$ E2\% 80\%9 Ckronprins+haakon\%E2\%80 \%9D+launched+in+muggiano_140421.html 